\title{
Cell-Based Experimental Analysis of a Proton Exchange Membrane Fuel Cell (PEMFC)
}

\author{
Adem Y1maz $^{1 *}$, Seyfi ŞEVIKK ${ }^{2}$, Rifat YAKUT ${ }^{3}$ \\ ${ }^{1}$ Energy Systems Engineering, Faculty of Technology, Batman University, Batman, Turkey \\ ${ }^{2}$ Electrical and Energy, Vocational School of Technical Sciences, Hitit University, Çorum, Turkey \\ ${ }^{3}$ Machine and Manufacturing Engineering, Faculty of Technology, Batman University, Turkey \\ (ORCID: 0000-0001-7266-0866) (ORCID: 0000-0003-4063-0456) (ORCID: 0000-0003-0059-378)
}

\begin{abstract}
This study is focused on cell-based experimental analysis of Proton Exchange Membrane Fuel Cell (PEMFC) with sodium borohydride $\left(\mathrm{NaBH}_{4}\right)$. The change in cell-based voltage values of 10-cell PEM fuel cell at two different temperatures was evaluated by keeping at constant load NaBH4, pure water and citric acid $\left(\mathrm{C}_{6} \mathrm{H}_{8} \mathrm{O}_{7}\right)$ which is used as a catalyzer. $3 \mathrm{~g} \mathrm{NaBH}_{4}, \mathrm{H}_{2} \mathrm{O} / \mathrm{NaBH}_{4}: 2 \mathrm{~mol} / \mathrm{mol}(\mathrm{x}=0)$, and $\mathrm{C}_{6} \mathrm{H}_{8} \mathrm{O}_{7}$ catalyzer $/ \mathrm{NaBH}_{4}: 0.1 \mathrm{~g} / \mathrm{g}$ and $250 \mathrm{~cm}^{3}$ of reactor volume production were realized. When the water temperature was raised to $60{ }^{\circ} \mathrm{C}$ from $40{ }^{\circ} \mathrm{C}$, total voltage value increased by $6.1 \%$. While, in the experiment of $40^{\circ} \mathrm{C}$, the interchange in voltage values were between 0.53 $\mathrm{V}$ and $0.78 \mathrm{~V}$, the mean values in the experiment of $60^{\circ} \mathrm{C}$ were between $0.61 \mathrm{~V}$ and $0.79 \mathrm{~V}$.
\end{abstract}

Keywords: PEM fuel cell, Sodium borohydride, Hydrolysis, Performance

\section{Proton Değişim Membran Yakıt Hücresinin (PDMYH) Hücre Bazlı Deneysel Analizi}

\section{Öz}

$\mathrm{Bu}$ çalışma, sodyum borhidrür $\left(\mathrm{NaBH}_{4}\right)$ kullanılan bir proton değiştirme membranı (PEM) yakıt pilinin hücre bazlı deneysel analizi üzerine odaklanmıştır. $\mathrm{NaBH} 4$, saf su ve katalizör olarak kullanılan sitrik asit $\left(\mathrm{C}_{6} \mathrm{H}_{8} \mathrm{O}_{7}\right)$ sabit yükte tutularak iki farklı sıcaklıkta 10 hücreli PEM yakıt pilinin hücre bazlı gerilim değerlerindeki değişim değerlendirilmiştir. $3 \mathrm{~g} \mathrm{NaBH}_{4}, \mathrm{H}_{2} \mathrm{O} / \mathrm{NaBH}_{4}: 2 \mathrm{~mol} / \mathrm{mol}(\mathrm{x}=0)$ ve $\mathrm{C}_{6} \mathrm{H}_{8} \mathrm{O}_{7}$ katalizörü/ $\mathrm{NaBH}_{4}: 0.1 \mathrm{~g} / \mathrm{g}$ ile $250 \mathrm{~cm}^{3}$ reaktör hacminde hidrojen üretimi gerçekleştirilmiştir. Su sıcaklığ $40{ }^{\circ} \mathrm{C}$ 'den $60^{\circ} \mathrm{C}$ 'ye çıkarıldığında toplam gerilim değeri $\% 6.1$ oranında artmıştır. $40{ }^{\circ} \mathrm{C}$ deneyinde ortalama gerilim değerleri $0.53 \mathrm{~V}$ ila $0.78 \mathrm{~V}$ arasında değişirken $60^{\circ} \mathrm{C}$ deneyinde ise ortalama değerler $0.61 \mathrm{~V}$ ila $0.79 \mathrm{~V}$ arasında değişmiştir.

Anahtar kelimeler: PDM yakıt pili, Sodyum borhidrür, Hidroliz, performans

\section{Introduction}

While the whole world embarks on a new quest about alternative energy sources, on the other hand, people make an effort to save and improve available energy sources. Hydraulic, solar and wind energies are seen as the most important renewable resources, and investments are made in them, as well. Mainly, fuel cells are categorized according to the type of electrolyte or fuel. These may be listed as: Proton exchange membrane fuel cell (PEMFC) which is commonly used because of its low operating temperature, direct methanol fuel cell, phosphoric acid fuel cell, alkali fuel cell, solid oxide fuel cell and molten carbonate fuel cell. Although studies on fuel cell technology, which provide productivity by using hydrogen energy, started nearly 200 years ago, full-scale practices have just begun to take place. After all, plenty of studies have been conducted on PEM fuel cells [1-4] and renewable energy resources based on PEM fuel cells [5-8]. Generating hydrogen by sodium borohydride $\left(\mathrm{NaBH}_{4}\right)$ is another subject

*Sorumlu yazar: adem.yilmaz@batman.edu.tr

Geliş Tarihi: 25.03.2019, Kabul Tarihi: 06.08.2019 
for this study, and there are a lot of studies in this field [9-13]. The characteristics of hydrogen and sodium borohydride are shown in Table 1 . Hydrogen gas for fuel cells may be generated by electrolyzing water from natural gas or by using $\mathrm{NaBH}_{4}$ which is thought as an important hydrogen storage method and a compound of boron which is produced under special conditions in which hydrogen gas can be stored. Hydrogen can be stored in various solid and liquid compounds (metal hydrides, nano carbon structures, alanates, borohydrides, methane, methanol and light hydrocarbon) as a chemical or physicochemical process [1].

Table 1. The characteristics of sodium borohydride and hydrogen

\begin{tabular}{lll}
\hline Properties & $\mathrm{H}_{2}$ & $\mathrm{NaBH}_{4}$ \\
\hline Atomic Weight $(\mathrm{g} / \mathrm{mol})$ & 1.00794 & --- \\
Density $\left(\mathrm{kg} / \mathrm{m}^{3}\right)$ & 0.08988 & 107000 \\
Bulk Density $\left(\mathrm{kg} / \mathrm{m}^{3}\right)$ & --- & $350-500$ \\
Theoretical $\mathrm{H}_{2}$ coverage $($ weight, $\%)$ & --- & 10.6 \\
Gas constant $(\mathrm{kJ} / \mathrm{kgK})$ & 4.124 & --- \\
Upper heating value $(\mathrm{MJ} / \mathrm{kg})$ & 140.9 & --- \\
Melting point $\left(\right.$ Under $2-6 \mathrm{~atm} \mathrm{H}_{2}$ pressure) $\left({ }^{\circ} \mathrm{C}\right)$ & --- & 500 \\
Lower heating value $(\mathrm{MJ} / \mathrm{kg})$ & 120.7 & --- \\
Specific heat $(\mathrm{kJ} / \mathrm{kgK})$ & 14.309 & --- \\
Degradation heat $(\mathrm{vacuum})\left({ }^{\circ} \mathrm{C}\right)$ & -- & 400 \\
Standard chemical exergy $(\mathrm{kJ} / \mathrm{kg})$ & 117113.095 & --- \\
$1 \mathrm{~kg} \mathrm{H} \mathrm{H}_{2}=$ & $2.1 \mathrm{~kg}$ gas & --- \\
Capacity heat $\left(25{ }^{\circ} \mathrm{C}, \mathrm{J} / \mathrm{mol} \mathrm{K} \mathrm{h}\right)$ & --- & 86.8 \\
\hline
\end{tabular}

Schelesinger et al. conducted research on using $\mathrm{NaBH}_{4}$ (as a reducing agent for hydrolysis) in generating hydrogen in 1953 [9]. Moreover, a research and development activity, which was about getting $\mathrm{NaBH}_{4}$ and its direct usage in fuel cells, was conducted by TUBITAK Marmara Research Center (TÜBİTAK MAM) and National Boron Research Institute (BOREN) [13]. The performance of fuel cells may vary in accordance with materials that are used, catalyzer, humidity and even rate of compression. $\mathrm{Xu}$ et al. (2007) stated that when a PEMFC is operated at high temperature, a slippage occurs in the cells [3]. Conformably, the amount of hydrogen that is generated as a result of the reaction varies depending on the volume, concentration and temperature of the sodium borohydride solution [14]. Increasing the temperature and using a catalyzer accelerate the reaction [15].

The Computational Fluid Dynamics (CFD) method was utilized to examine different designs, and the effects of each value of the variable flow rate on pressure decrease were investigated. Different models and designs were prepared [16-17]. Using MATLAB, in the study which was carried out on the general performance and efficiency of PEM fuel cells, program codes were written to create polarization curves for a single stack and a fuel cell consisting of five stacks. As a result, it was concluded that the open circuit voltage that was created was lower. According to the literature review, these results were not good. More water will be produced in the cathode part of the fuel cell, and therefore, it is an effective method to improve the performance of the fuel cell [18]. Models of PEMFC are examined based on the relevant literature in which studies have shown components and functions of PEMFC briefly. The water in a PEMFC may be managed depending on temperature, and it is important to remove the wastewater of a PEMFC quickly to achieve high efficiency and to make sure water management is facilitated. Thus, the water composition rate should be kept higher than the water evaporation rate. In this balance, an operational temperature should be low. The anode and cathode are utilized for the reaction of hydrogen and oxygen (air). Anode and cathode are normally kept in a dry state. The reaction of fuel cell gases should be moist for a good performance. As a result, the efficiency of the PEMFC may be increased at $80{ }^{\circ} \mathrm{C}$ [19]. A study was carried out on a more efficient and innovative prototype of a hydrogen production system using a PEM electrolyzer. A new system that uses hydrogen gas energy to transmit chemical reactions by electrolytic movements and new technology was designed to produce energy from $\mathrm{H}_{2}$. Cr-C-coated SS304 bipolar plates were used in the electrolysis. The performance of the electrolysis process was determined based on the parameters of current and voltage. In the system, production of hydrogen gas (1 MW) was calculated as $6 \mathrm{~m}^{3} \mathrm{~h}^{-1}$, and the simple payback period (SPP) was found as 2.32 y [20]. 
In PEM fuel cells, it is aimed to reach the optimal water conditions as well as fuel cell performance. In another study, platinum-plated catalyzed anode performance was shown for a process of micro-scale modeling experimentally in a study on PEM fuel cells. Hence, the authors observed timedependent voltage and current parameter changes for the performance analysis in their research. Their study aimed to find the optimal values of a few parameters (pressure, flow rate, voltage) for evaluating the performance of the fuel cell. They found the mean value of $2.62 \times 10-^{7}[\mathrm{~kg} / \mathrm{s}]$ for water production and generated an energy level of $42.5[\mathrm{~kJ}] \mathrm{H}_{2}$. Consequently conclusion, they reached a performance efficiency value of approximately $52 \%$ [21]. In an experimental analysis of electricity generation with sodium borohydride $\left(\mathrm{NaBH}_{4}\right)$ assisted hydrogen/air PEMFC, it has been observed that $\mathrm{NaBH}_{4}$ hydrolysis produces hydrogen gas even at low temperatures and the reaction rate continues stable for a long time [22]. Experiments started with the measurement of the voltage value 5.6 V DC and the current value $0.3 \mathrm{~A}$, and they continued almost constant until the 64th min however, they decreased rapidly in values between 64 and 81 mins.

The present study investigates the experimental performance of PEM fuel cell. In study, the temperature at the hydrolysis reactor and voltage generation of each cell were analyzed on a system that was created by combining $\mathrm{H}_{2}$ and PEM fuel cells with 10 cells that were generated in the hydrolysis reactor.

\section{Material and Method}

Experimental setup: $\mathrm{H}_{2(\mathrm{~g})}$ generation tank, $\mathrm{H}_{2(\mathrm{~g})}$ humidification unit, a PEM fuel cell with 10 cells, led light unit with fan and microcontroller. The experimental setup of a $\mathrm{NaBH}_{4}$ supported hydrogen/air fuel cell is shown in Fig. 1. Power generation was achieved by burning $\mathrm{H}_{2}$, which was generated in fuel cell in the system.

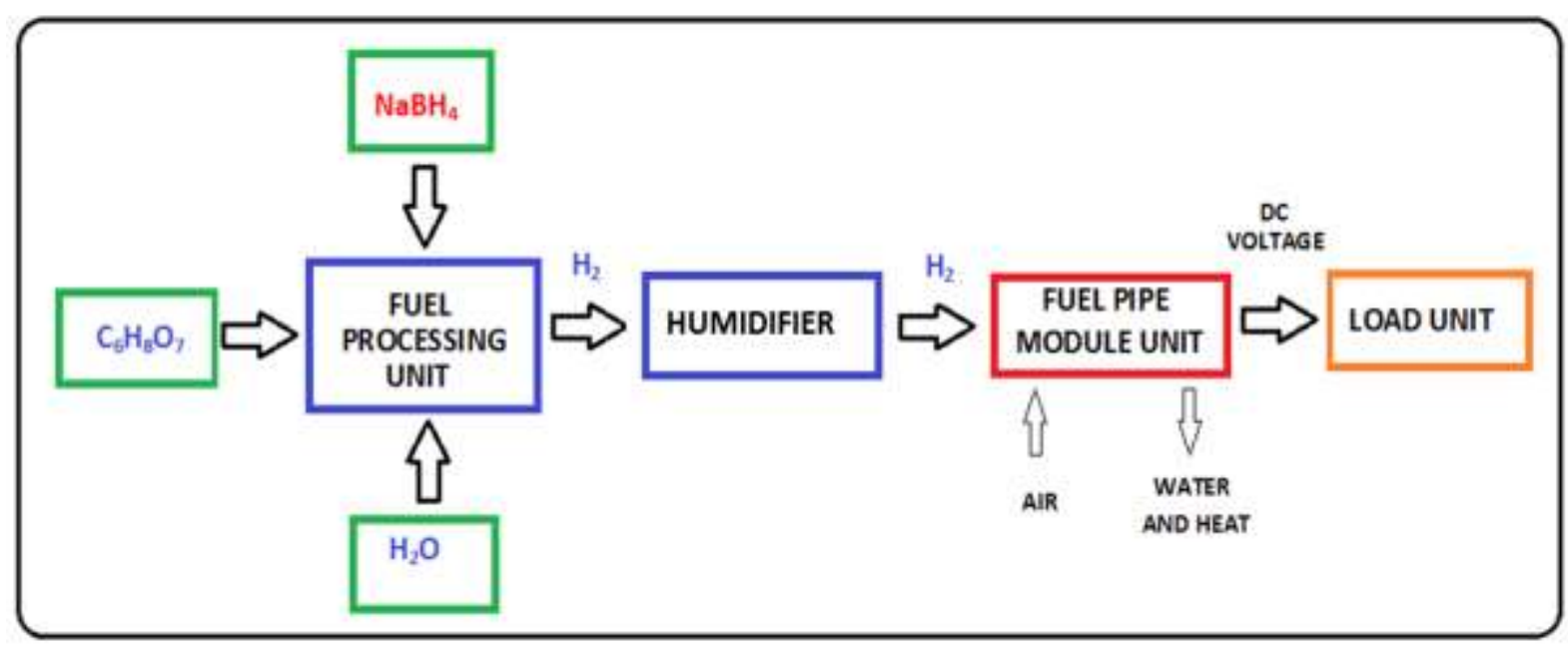

Figure 1. The experimental setup of a $\mathrm{NaBH}_{4}$ supported hydrogen/air fuel cell

The PEM fuel cell in the system consisted of bipolar plates, electrodes, a catalyzer, a membrane, current collectors and seals. The fuel in the fuel cell could generate electric energy as long as it was input to the system. Fig. 2 shows the block diagram of a fuel cell that transmits protons. 


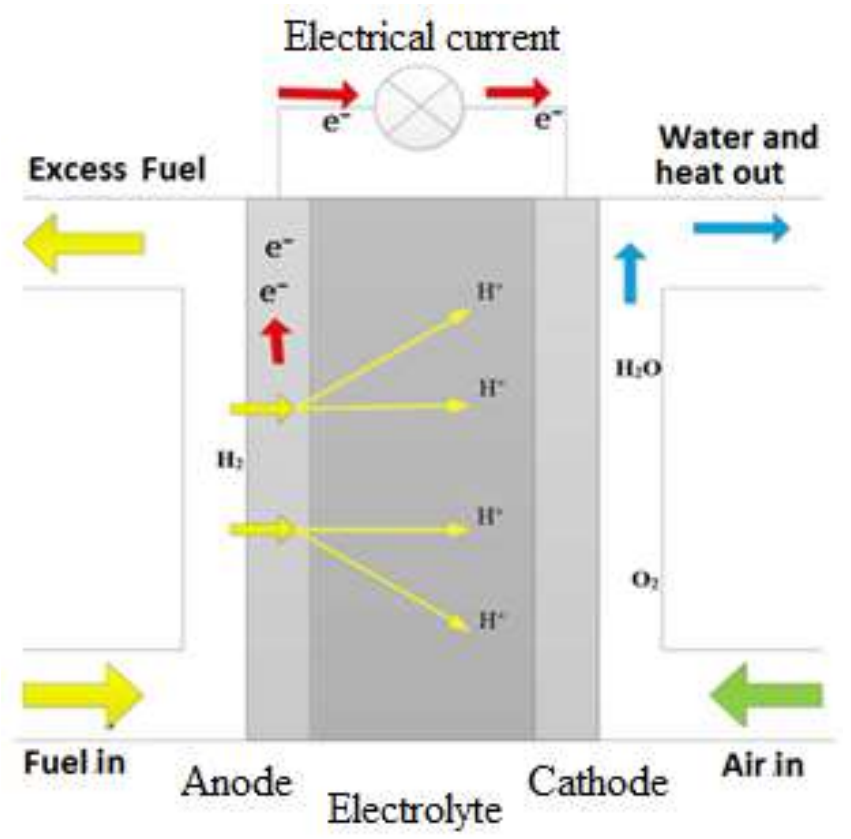

Figure 2. The block diagram of a fuel cell that transmits protons [4]

The fundamental reactions that were facilitated in the fuel cell are shown in the equations below;

Anode side: $\mathrm{H}_{2} \rightarrow 2 \mathrm{H}^{+}+2 \mathrm{e}^{-}$

Cathode side: $1 / 2 \mathrm{O}_{2}+2 \mathrm{H}^{+}+2 \mathrm{e}^{-} \rightarrow \mathrm{H}_{2} \mathrm{O}$

General reaction: $\mathrm{H}_{2}+1 / 2 \mathrm{O}_{2} \rightarrow \mathrm{H}_{2} \mathrm{O}$

$\mathrm{NaBH}_{4}$, which is used to generate $\mathrm{H}_{2}$, is a product that has a high-level hydrogen storage density in weight and volume. By using this product, hydrogen generation can be achieved with a high-level purity.

$\mathrm{NaBH}_{4} \rightarrow \mathrm{Na}+\mathrm{B}+\mathrm{H}_{2}$

Because of the reason that $\mathrm{NaBH}_{4}$ concretely reacts, a catalyzer is necessary for controlling and activation of generation of $\mathrm{H}_{2}$ gas. Catalyzers such as $\mathrm{Co}, \mathrm{Ni}, \mathrm{Pt}-\mathrm{TiO}_{2}, \mathrm{Pt}-\mathrm{CoO}$, and $\mathrm{Pt}-\mathrm{LiCoO}_{2}$ have been used in other studies. The reaction shown in Eq. 5 makes it possible to store hydrogen in aqueous solutions with high weight density. As it is in Eq. 1, Hydrolysis of $\mathrm{NaBH}_{4}$ is an exothermic reaction which releases hydrogen gas [9]:

$\mathrm{NaBH}_{4}+(2+\mathrm{x}) \mathrm{H}_{2} \mathrm{O} \rightarrow$ Catalyzer $\rightarrow \mathrm{NaBO}_{2} \mathrm{xH}_{2} \mathrm{O}+4 \mathrm{H}_{2}+$ Heat

Here, $\mathrm{x}$ is a hydration factor, and it is obtained for $\mathrm{x}=0$, which is the ideal hydrolysis condition [23]. To release 4 mol of $\mathrm{H}_{2}, 1 \mathrm{~mol}$ is necessary. Moreover, to react with $\mathrm{NaBH}_{4}, 2$ mol of $\mathrm{H}_{2} \mathrm{O}$ is necessary. In practice, the excess of water is necessary to be able to explain that a solid by-product $\left(\mathrm{NaBO}_{2} \cdot \mathrm{xH}_{2} \mathrm{O}\right)$ can exist on different hydration levels.

Pure $\mathrm{NaBH}_{4}$ contains $10.6 \%$ hydrogen by weight, but to be able to obtain hydrogen in gas form, there must be a catalytic hydrolysis reaction with water. When it reacts with water, total amount of $\mathrm{H}_{2}$ that is obtained from $\mathrm{NaBH}_{4}$ increases and reaches $21.2 \%$ by weight. In the experimental setup, different temperatures were created in the hydrolysis tank, and an analysis was conducted on the cell-based power generation of the fuel cell. $25 \mathrm{ml}$ of water was added into the humidifier. For each experiment, at 40 and $60{ }^{\circ} \mathrm{C}, 120 \mathrm{ml}$ of water was filled into hydrolysis tank, and $3 \mathrm{~g}$ of $\mathrm{NaBH}_{4}$ was added. To increase the rate of reaction in a perceivable way, as a catalyzer, $0.3 \mathrm{~g}$ of citric acid $\left(\mathrm{C}_{6} \mathrm{H}_{8} \mathrm{O}_{7}\right)$ was added to control 
and activate $\mathrm{H}_{2}$ generation. The generated $\mathrm{H}_{2}$ goes out from the humidifier as bubbles and into the fuel cell by using the $\mathrm{H}_{2}$ entrance channel of the PEM fuel cell. After a little while, it generates power in the fuel cells.

\section{Theoretical Analysis of the System}

In the experimental study, the voltage at the output of the fuel cell can be measured by using the Fluke 43B measuring device with three minutes of intervals. A power calculation can be made by using the received value as it is shown below.

Power $(P)=$ Voltage $($ V) $x$ Current $(I)$

Unloaded Voltage $(\mathrm{E})$; activation $\left(\mathrm{V}_{\text {act }}\right)$, ohmic $\left(\mathrm{V}_{\mathrm{ohm}}\right)$ and concentration $\left(\mathrm{V}_{\text {conc }}\right)$ are reduced by overvoltage. Cell Voltage $\left(\mathrm{V}_{\text {cell }}\right)$;

$V_{\text {cell }}=E-V_{\text {act }}-V_{\text {ohm }}-V_{\text {conc }}$

The real cell voltage can be written like the following;

$V_{\text {cell }}=V_{e q}-\mu$

Here, at the experimental cell voltage from the $\mathrm{V}_{\text {cell }}$ polarization curve, $\mathrm{V}_{\mathrm{eq}}$ is the theoretical cell equilibrium potential (it equals the difference between cathode equilibrium potential and anode equilibrium potential), and $\mu$ is the total overvoltage.

The stack voltage of series of cells $\left(\mathrm{V}_{\text {stack }}\right)$;

$\mathrm{V}_{\text {stack }}=\mathrm{V}_{\text {cell }} \mathrm{X}$ number of cells

Depending on Gibbs free energy, the maximum electrical energy value that can be generated in a fuel cell is calculated like the following;

$\mathrm{W}_{\mathrm{el}}=-\Delta \mathrm{G}$

Theoretical potential of fuel cell:

$\mathrm{E}=-\Delta \mathrm{G} / \mathrm{nF}$

Here, $\mathrm{n}$ and $\mathrm{F}$ are constants, $\mathrm{n}$ is the number of transmitted electrons during the reaction, and $\mathrm{F}$ is Faraday's constant (96.485 coulomb/electron mol). According to this, under atmospheric pressure and a temperature of $25^{\circ} \mathrm{C}$, the theoretical hydrogen/oxygen fuel cell potential [24]:

$\mathrm{V}_{\text {teo }}=-\Delta \mathrm{G} / \mathrm{nF}=(237.340 \mathrm{~J} / \mathrm{mol}) /(2 \times 96.485 \mathrm{As} / \mathrm{mol})=1.23 \mathrm{Volt}$

In theory, $1.229 \mathrm{~V}$ can be obtained from a fuel cell. However, because of the polarization in fuel cells, this value cannot be obtained, and actually, this voltage falls under $1 \mathrm{~V}$ because of polarization. A typical PEM fuel cell can generate a voltage between $0.6 \mathrm{~V}$ and $0.7 \mathrm{~V}$. The decrease in voltage occurs based on activation loss, cell components, resistance of inner links and volume polarization. So, the real value is lower than the theoretical value. The increase in the number of cells in a stack increases the voltage. Nevertheless, if the surface area is increased, the current increases.

If all the Gibbs free energy is transmitted into electrical energy, the maximum theoretical fuel cell efficiency is [24];

$\eta=\Delta \mathrm{G} / \Delta \mathrm{H}=237.34 / 286.02=83 \%$ 
The rate of the operating voltage to the ideal voltage is formulized as follows:

$\eta_{\mathrm{v}}=-\mathrm{V}_{\mathrm{g}} / \mathrm{V}_{\mathrm{i}}$

\section{Experimental Studies and Methods}

The experiments were carried out at the Energy Systems Engineering Laboratory at the Faculty of Technology at Batman University. The experiments were conducted by utilizing hydrogen gas obtained by using $\mathrm{NaBH}_{4}$ in a small PEMFC. Instead of pure oxygen, the air coming from the fan that was used for cooling was utilized as an oxygen source. The gas that was obtained as a result of separation of hydrogen absorbed into $\mathrm{NaBH}_{4}$ was used. Various temperature values were used in the degradation of $\mathrm{NaBH}_{4}$. The experiments started with water at the ambient temperature of $20{ }^{\circ} \mathrm{C}$. The experiments continued up to the temperature of $90{ }^{\circ} \mathrm{C}$. The ideal power was reached at $40{ }^{\circ} \mathrm{C}$ and $60{ }^{\circ} \mathrm{C}$ on average.

\section{Results and Discussion}

The experimental setup was prepared as it was mentioned in the previous part, and it was operated to generate $\mathrm{H}_{2}$ and DC voltage. In the $\mathrm{NaBH}_{4}$ hydrolysis experiments, the temperature of mixing in the hydrolysis tank was determined as $40{ }^{\circ} \mathrm{C}$ and $60{ }^{\circ} \mathrm{C}$, and the experiments were then started. For 30 minutes of the experiment, the effect of temperature on yield was observed. While the experimental setup was operating, weight loss, voltage and heat values were measured. $3 \mathrm{~g} \mathrm{NaBH}, \mathrm{H}_{2} \mathrm{O} / \mathrm{NaBH}_{4}: 2$ $\mathrm{mol} / \mathrm{mol}(\mathrm{x}=0)$ and $\mathrm{C}_{6} \mathrm{H}_{8} \mathrm{O}_{7}$ catalyzer $/ \mathrm{NaBH}_{4}$ : generates hydrogen $0.1 \mathrm{~g} / \mathrm{g}$ and $250 \mathrm{~cm}^{3}$. At $40{ }^{\circ} \mathrm{C}$ and 60 ${ }^{\circ} \mathrm{C}$, distilled water was added to hydrolysis tank. In Fig. 3, the change (depending on time) in the temperature of the hydrolysis tank is displayed.

When the water was mixed with $\mathrm{NaBH}_{4}$, temperature increase started. During the experiments, the temperature reached the highest level in the $6^{\text {th }}$ minute. Later, a gradual decrease was observed in the temperature values. In the $40{ }^{\circ} \mathrm{C}$ experiment, the mixing temperature reached $55{ }^{\circ} \mathrm{C}$ and started to decrease in the $12^{\text {th }}$ minute. However, in the $30^{\text {th }}$ minute, it decreased till $49^{\circ} \mathrm{C}$. In the $60^{\circ} \mathrm{C}$ experiment, it reached the maximum of $71^{\circ} \mathrm{C}$. Again, the temperature decrease was realized in the $12^{\text {th }}$ minute and resulted in the value of $56{ }^{\circ} \mathrm{C}$ value. Indeed, when the temperature value was high in the hydrolysis tank, it allowed an easier decomposition for hydrolysis temperature in high values during the experiment. In the $40{ }^{\circ} \mathrm{C}$ experiment, while an increase of $15^{\circ} \mathrm{C}$ was observed the mixing temperature according to the first temperature, the increasing rate was $11{ }^{\circ} \mathrm{C}$ for the $60{ }^{\circ} \mathrm{C}$ experiment. The $40{ }^{\circ} \mathrm{C}$ and $60{ }^{\circ} \mathrm{C}$ experimental values are compared in Fig. 3 and having a high mixing temperature means that hydrogen is effective in the decomposition process. While the mixing temperature increased in the hydrolysis tank, it was seen that the decomposition was faster and longer.

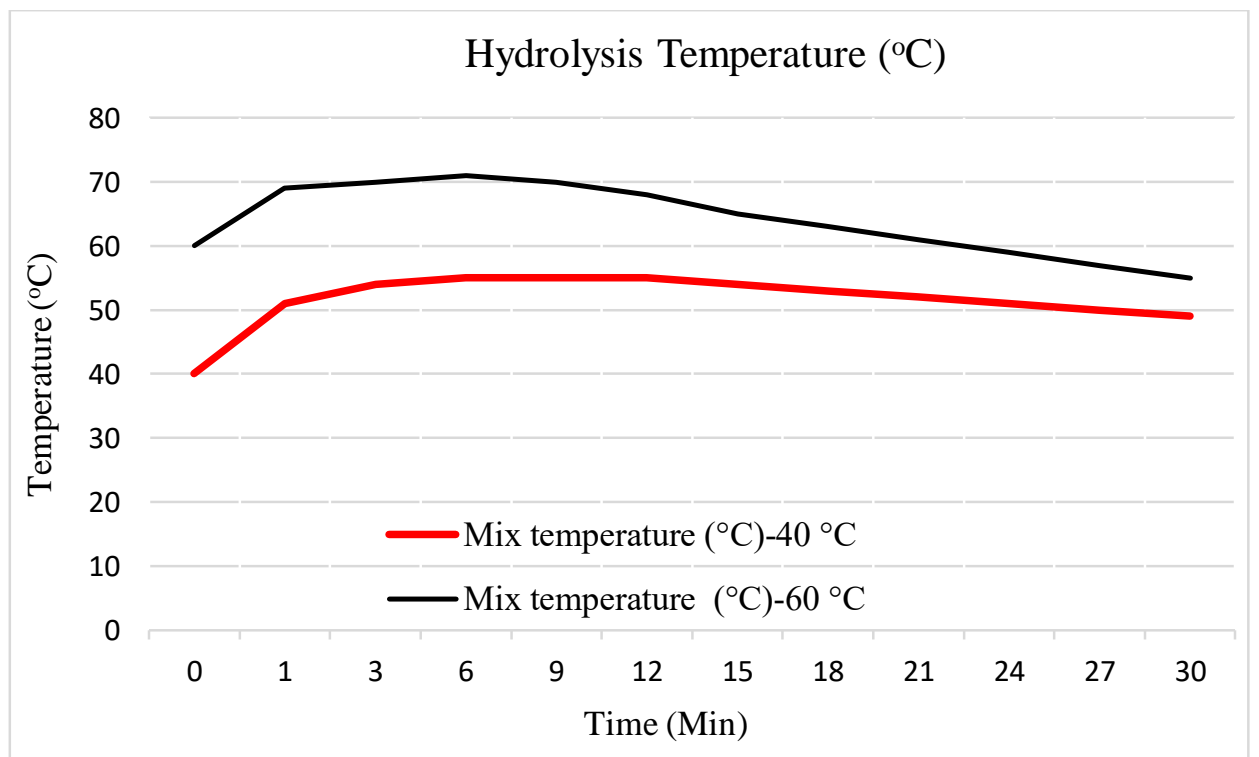

Figure 3. The change of temperature in hydrolysis depending on time 
Fig. 4 shows the change in the weight loss of the hydrolysis tank depending on time. At both temperatures, weight loss was nearly the same, but the loss at $40{ }^{\circ} \mathrm{C}$ was 0.6 lower than the other. Even though there was $20^{\circ} \mathrm{C}$ temperature difference between the experiments, realizing a little weight loss between the two experiments revealed the effect of temperature increase on weight. While having a high mixing temperature in the hydrolysis tank provides more decomposition for $\mathrm{NaBH}_{4}$ hydrolysis inside water, this loss shows the increase of hydrogen formation in $60{ }^{\circ} \mathrm{C}$. So, this increase provides a fair of amount rise for the energy production values.

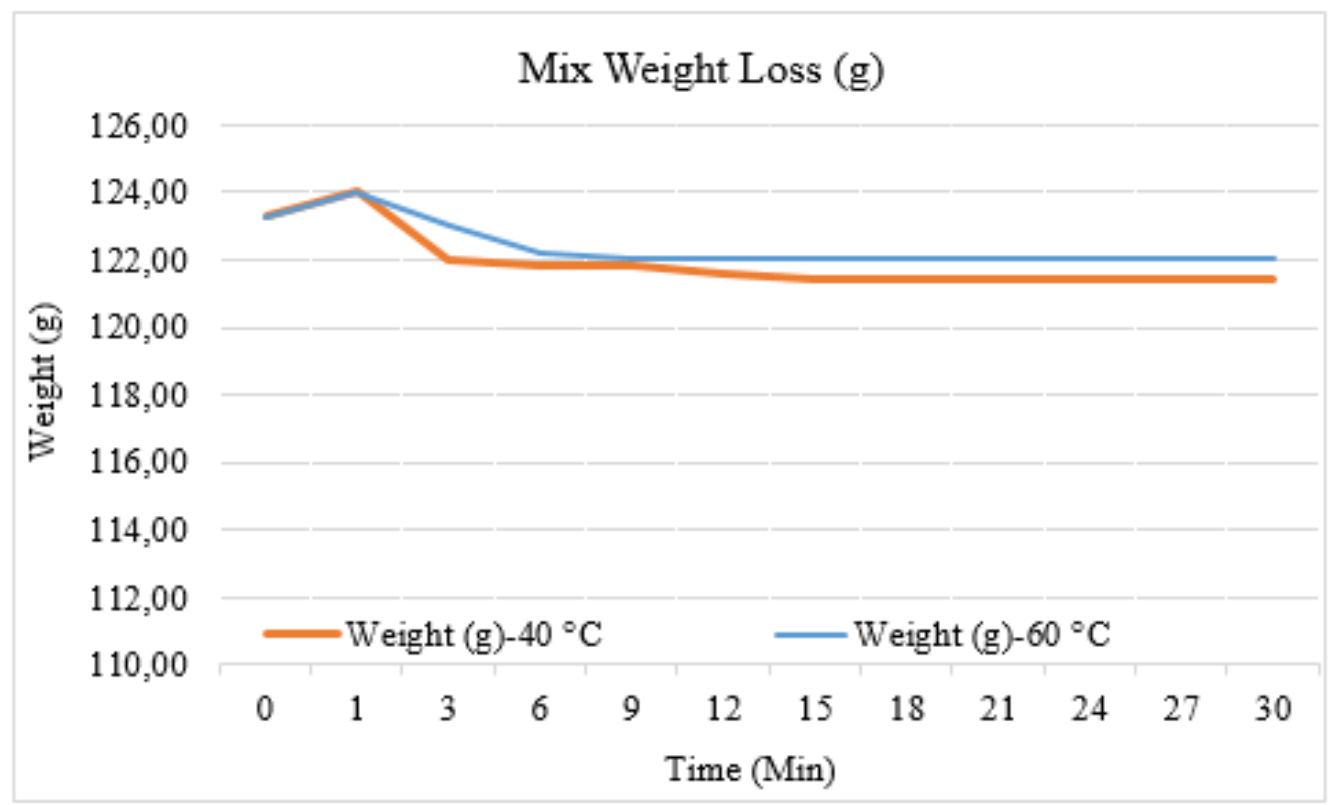

Figure 4. The weight loss in hydrolysis tank

In Fig. 5, a cell-based voltage rating in stack is given, and this value also depended on time. The values were by the minimum $0.37 \mathrm{~V}$ and the maximum $0.86 \mathrm{~V}$ for the $40{ }^{\circ} \mathrm{C}$ experiment and minimum $0.45 \mathrm{~V}$ and maximum $0.83 \mathrm{~V}$ for the $60{ }^{\circ} \mathrm{C}$ experiment. When the voltage values each cell produced in a stack are examined in Fig. 5, a rapid increase in the first minute was observed. However, in the 3rd minute of the experiment, while a decrease was realized in the voltage values, which were produced in the former cells, it is seen that voltage values in the final cells kept increasing. The reason is that, as hydrogen combines completely with oxygen in the former cells, it generates the maximum values, and it may be considered that a maximum combination has not been realized in the final cells yet. During the experiments, oscillations in voltage values attracted attention. This oscillation meant that there was no complete combination inside the cell, and the water that was formed in combination could not be thrown out from the cell. Between the 15th and 24th mins, a stable situation in cells was observed except for the first cell. Because hydrogen access is achieved from the first cell, a complete transformation does not occur with the effect of hydrogen access speed, and in turn, this disables the generation in the cell.

Figs. 6 and 7 show the cell-based increase values for the $40{ }^{\circ} \mathrm{C}$ and $60{ }^{\circ} \mathrm{C}$ experiments. Figs. 6 and 7 provide the voltage values obtained from the experiments at $40{ }^{\circ} \mathrm{C}$ and $60{ }^{\circ} \mathrm{C}$. As seen in the figure, there was an increase or decrease in the voltage values obtained from the experiments at different intervals. The effect of each cell on total voltage may be clearly seen in the figure. While some cells were substantially effective on total voltage, some cells were less effective. In general, as the total voltage was under $6 \mathrm{~V}$ in the $40{ }^{\circ} \mathrm{C}$ experiment, the total voltage was above $6 \mathrm{~V}$ in the $60^{\circ} \mathrm{C}$ experiment. 


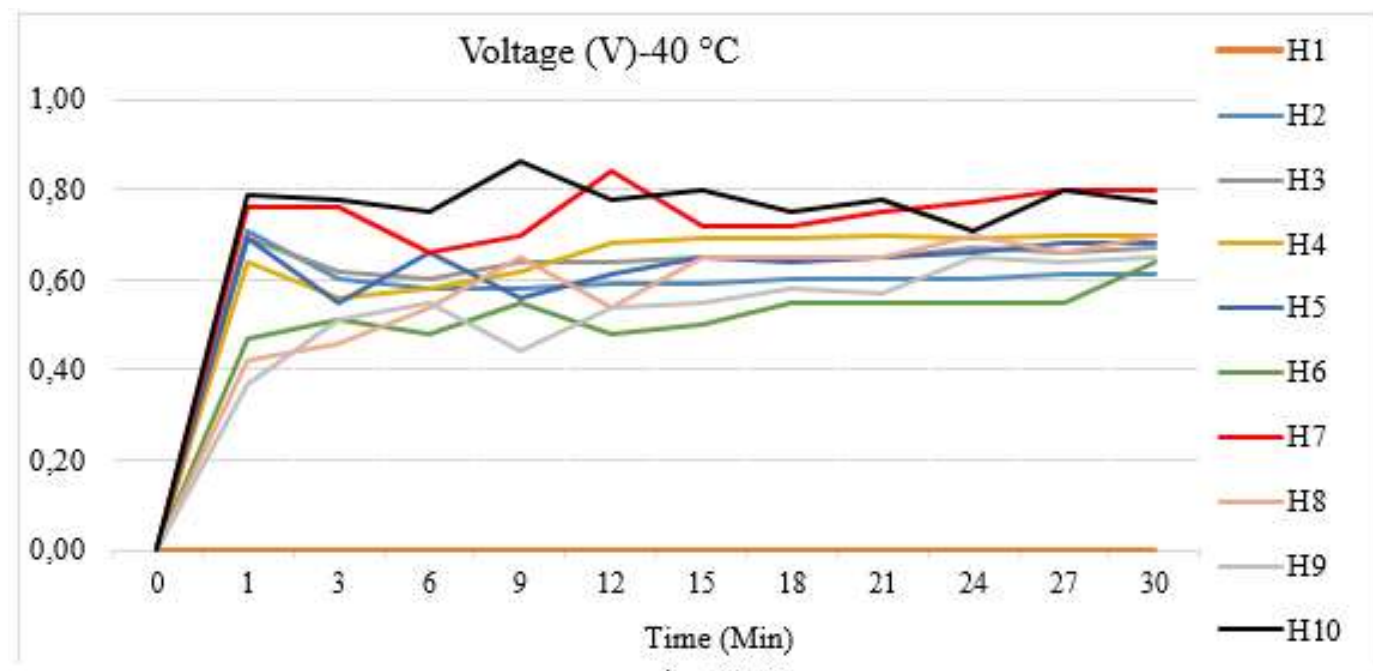

a) $40^{\circ} \mathrm{C}$

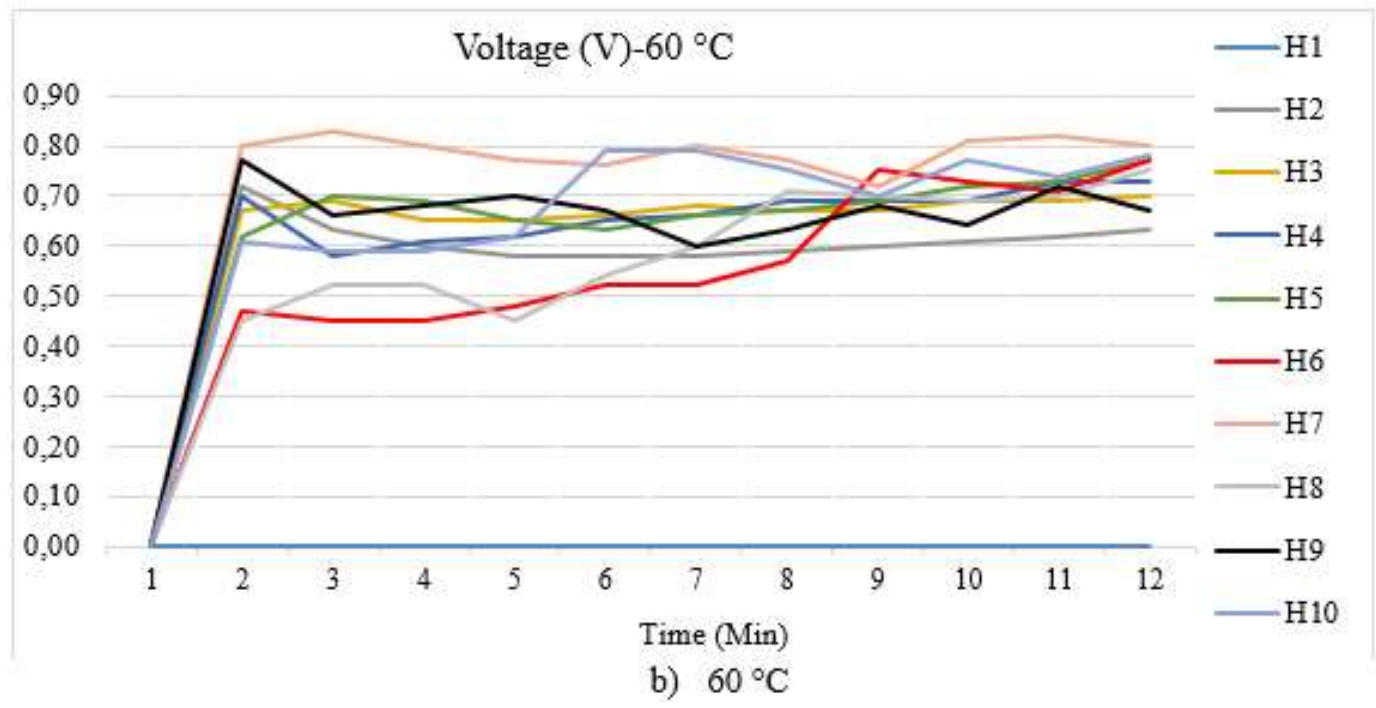

Figure 5. The cell-based voltage rating in the stack depending on time

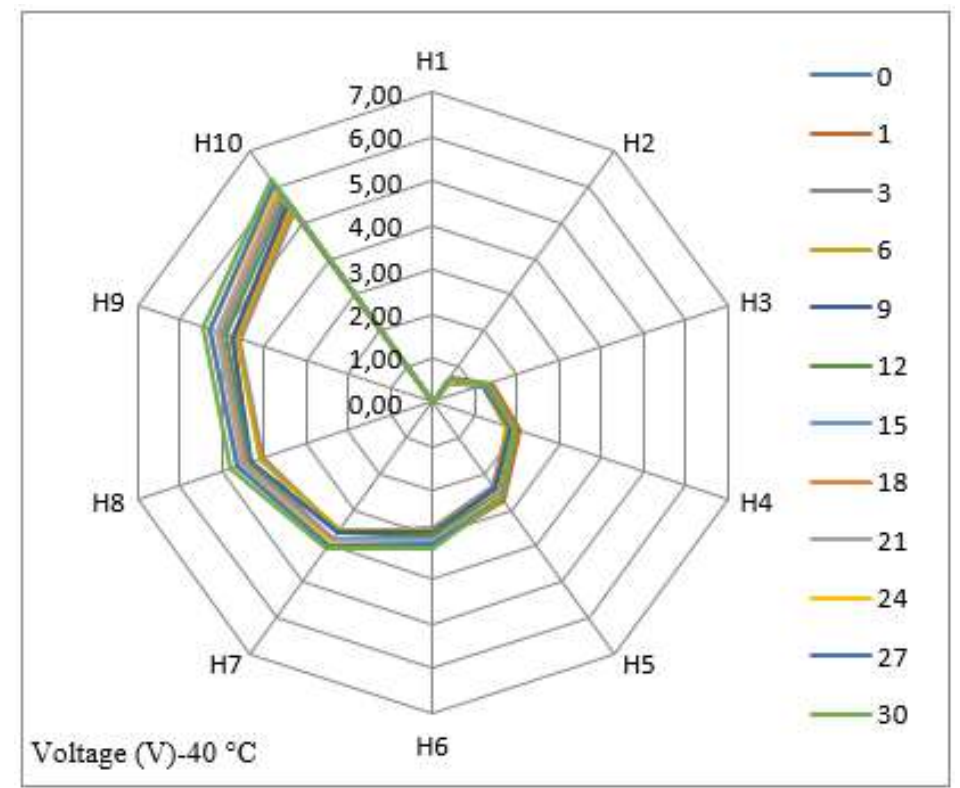

Figure 6. Increase in cell-based voltage rating in the stack for $40{ }^{\circ} \mathrm{C}$ experiment 


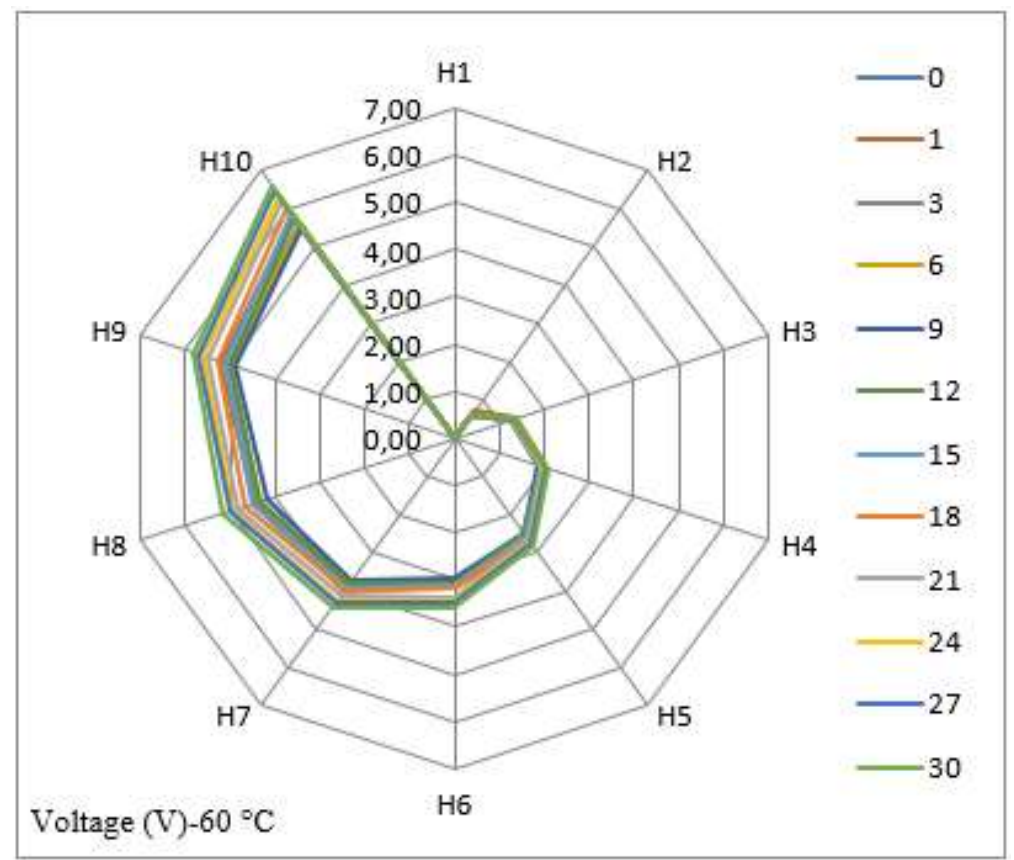

Figure 7. Increase in cell-based voltage rating in the stack for $60^{\circ} \mathrm{C}$ experiment

Figs. 8 and 9 show the total voltage rating of fuel cells. At the beginning of the experiment, the voltage values were high, and then, they decreased by a little. After this, they increased again. In the 60 ${ }^{\circ} \mathrm{C}$ experiment, when the total voltage rating was raised, there was a $6.1 \%$ increase.

Based on the total voltage values which were produced by PEMFC depending on time belonging to the $40{ }^{\circ} \mathrm{C}$ and $60{ }^{\circ} \mathrm{C}$ experiments, an increase in the voltage values in time may be observed, and this increase was clearly seen in the $40{ }^{\circ} \mathrm{C}$ experiment. As expected, the data obtained from the $60{ }^{\circ} \mathrm{C}$ experiment were higher than those obtained from the $40{ }^{\circ} \mathrm{C}$ experiment. The reason for this is that transformation in cells is more effective with the increase of hydrogen speed. Sometimes, voltages increase or decrease during experiments. The reasons for a voltage decrease are not being able to evacuate the water during transformation and lack of efficiency in transformation.

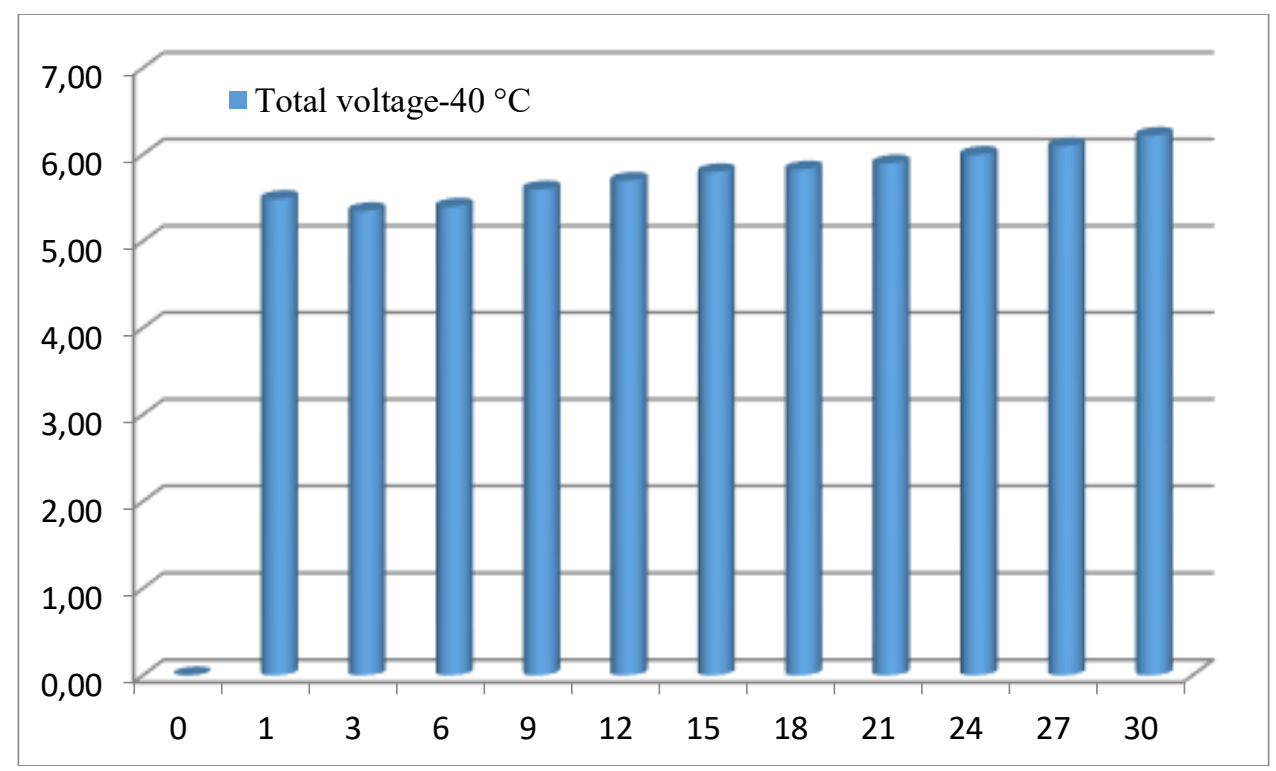

Figure 8. $40^{\circ} \mathrm{C}$ experiment, total voltage rating in fuel cell stack 


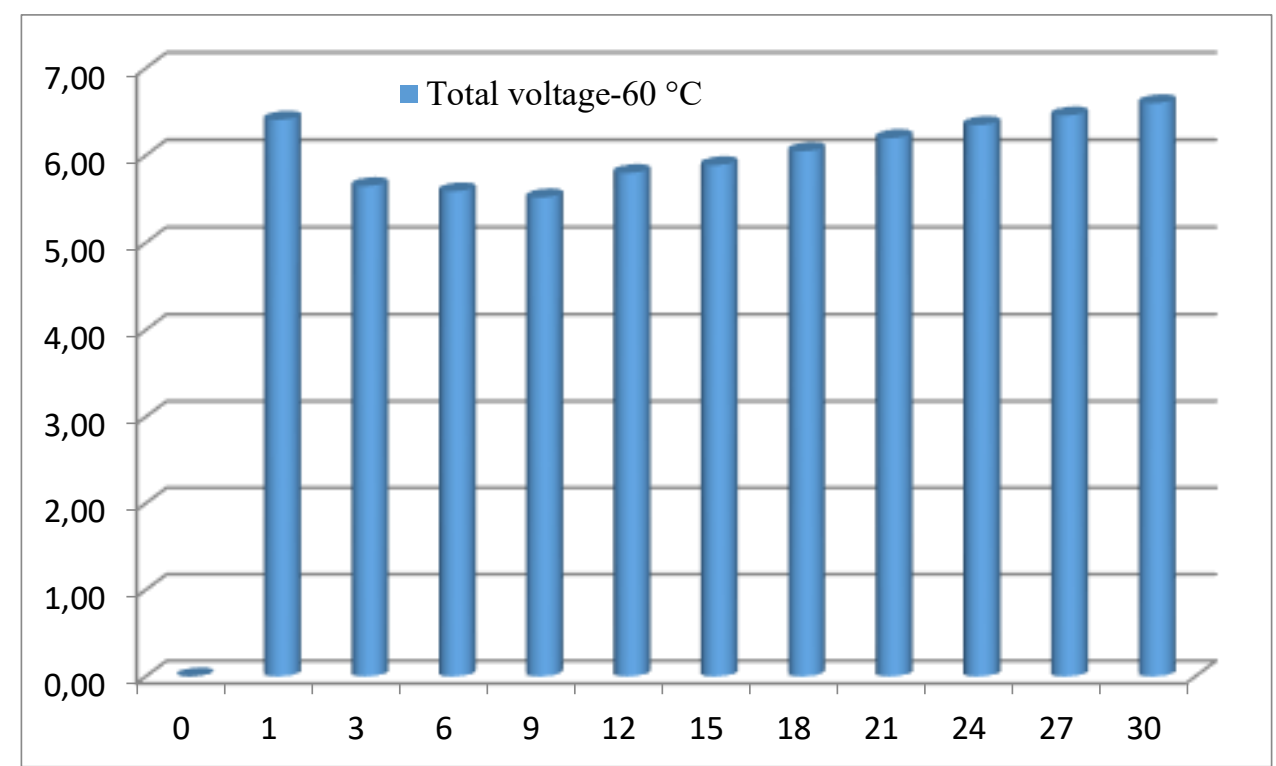

Figure 9. $60{ }^{\circ} \mathrm{C}$ experiment, total voltage rating in fuel cell stack

Figs.10 and 11 display the mean voltage values per cell. When the cell-based mean values were raised, the cells that had the numbers 7 and 10 had higher values, and the cell with the number 6 had the lowest value. Nevertheless, we could not get a value from the cell number 1 . In the $40{ }^{\circ} \mathrm{C}$ experiment, the mean voltage values varied from $0.53 \mathrm{~V}$ to $0.78 \mathrm{~V}$. In the $60{ }^{\circ} \mathrm{C}$ experiment, the values were between $0.61 \mathrm{~V}$ and $0.79 \mathrm{~V}$.

As seen in Figs 10 and 11, the mean values at $60{ }^{\circ} \mathrm{C}$ were higher than those at $40{ }^{\circ} \mathrm{C}$. Because of some reasons such as changes in hydrogen speed inside the cell and inability to evacuate the water that formed in the cells, fluctuations in generation were observed. It was seen in every figure that the first cell did not generate a current. The reason for this may be providing oxygen from upper fuel cell's plate as the fuel cell used in the experiment gets oxygen from its environment with the help of the cooling fan. When hydrogen hits the first plate, the oxygen comes up with the help of the fan. In this part, hydrogen probably passes through from first cell and but is not able to contact oxygen. Moreover, instead of oxygen gas, it was aerated air, and we made use of the oxygen inside the air.

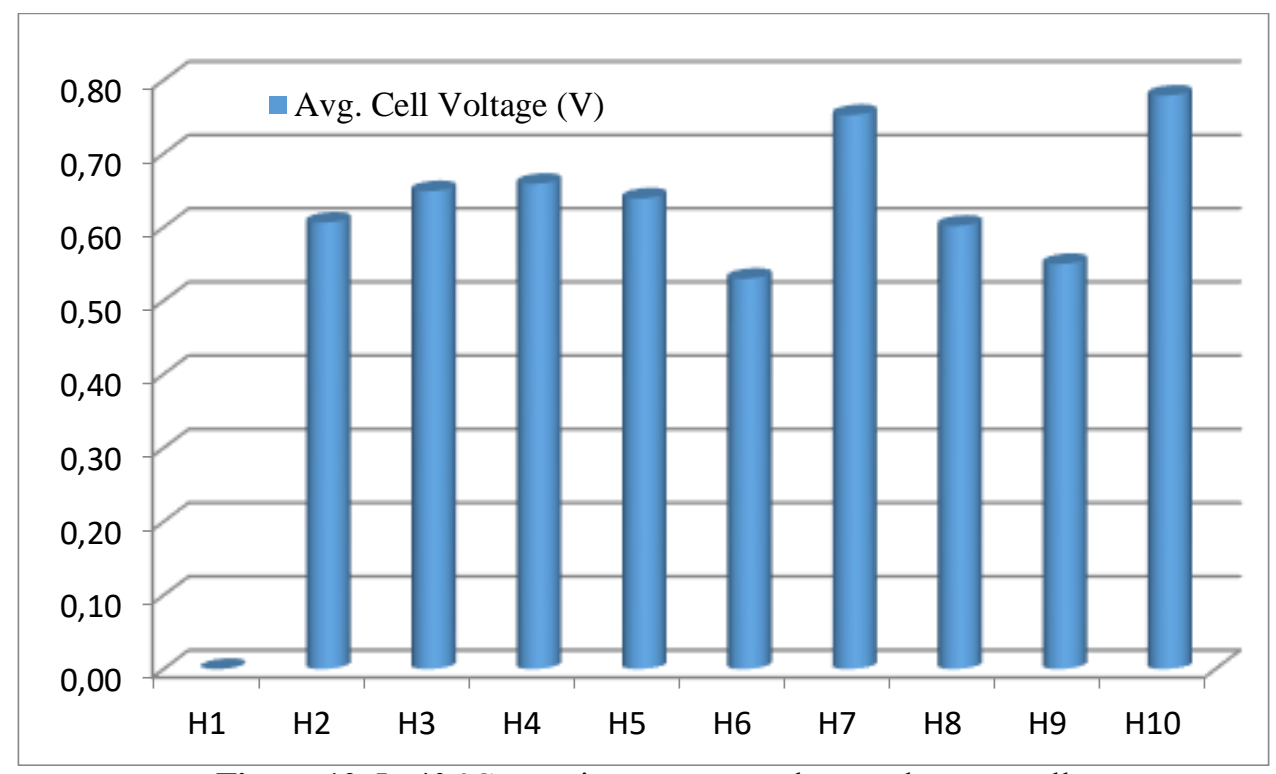

Figure 10. In $40{ }^{\circ} \mathrm{C}$ experiment, mean voltage values per cell 


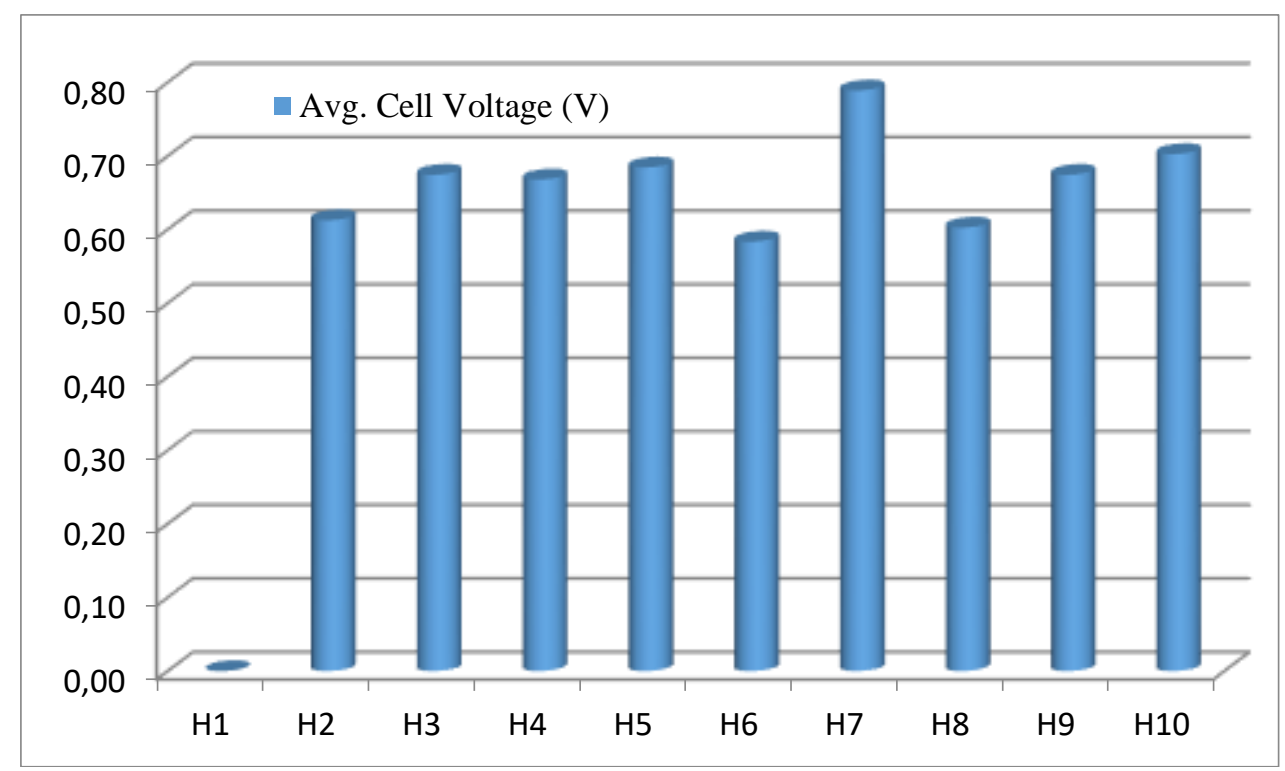

Figure 11. In $60^{\circ} \mathrm{C}$ experiment, mean voltage values per cell

As specified in reference [22], hydrogen gas was generated even at low temperatures however as specified in reference [3], PEMFC should not be operated at high temperature because of slippages in the cells. As specified in references [14,15,22], increasing the temperature and using a catalyzer accelerated the reaction and also the amount of hydrogen that is generated as a result of the reaction varied depending on the volume of $\mathrm{NaBH}_{4}$.

\section{Conclusion}

The effect of the temperature in a hydrolysis reactor on power generation and the performance of each cell were analyzed by using a $\mathrm{NaBH}_{4}$ hydrolysis reactor-supported PEMFC system. Although hydrogen gas generation was realized in $\mathrm{NaBH}_{4}$ hydrolysis with low temperatures, at higher temperatures, it was seen that $\mathrm{NaBH}_{4}$ could be decomposed in water easier, and there was an increase in the rate of the reaction. When the temperature was increased from $40{ }^{\circ} \mathrm{C}$ to $60{ }^{\circ} \mathrm{C}$, and when the total voltage rating was constant, $6.1 \%$ higher voltages were obtained, but it was observed that the temperature did not have an effect on power generation time. In the $40{ }^{\circ} \mathrm{C}$ experiment, the values were by the minimum $0.37 \mathrm{~V}$ and the maximum $0.86 \mathrm{~V}$. In the $60{ }^{\circ} \mathrm{C}$ experiment, the values were by the minimum $0.61 \mathrm{~V}$ and the maximum $0.79 \mathrm{~V}$. The cost of production and the marketing price of sodium borohydride need to decrease to be able to compete with fuels that are currently being used. If this happens, these kinds of products may become popular. In addition to this, if the cost of the membrane in fuel cells decreases, cell usage increases.

\section{References}

[1] Ma J., Su Y., Zhou Y., Zhang Z. 2003. Simulation and prediction on the performance of a vehicle's hydrogen engine. Int. J. Hydrogen Energy, 28: 77-83.

[2] Williams M.V., Russell Kunz H., Fenton J.M. 2005. Analysis of polarization curves to evaluate polarization sources in hydrogen/air PEM fuel cells. Electrochem. Soc., 152 (3): A635-A644.

[3] Xu H., Russell Kunz H.R., Fenton J.M. 2007. Analysis of proton exchange membrane fuel cell polarization losses at elevated temperature $120{ }^{\circ} \mathrm{C}$ and reduced relative humidity. Electrochim Acta, 52: 3525-33.

[4] Das V., Padmanaban S., Venkitusamy K., Selvamuthukumaran R., Blaabjerg F., Siano P. 2017. Recent advances and challenges of fuel cell based power system architectures and control-A review. Renewable and Sustainable Energy Review, 73: 10-18.

[5] Zoulias EI., Lymberopoulos N. 2007. Techno-economic analysis of the integration of hydrogen energy technologies in renewable energy-based stand-alone power systems. Renewable Energy, 32 (4): 680-696. 
[6] Dursun E., Kilic O. 2012. Comparative evaluation of different power management strategies of a stand-alone PV/Wind/PEMFC hybrid power system. Electrical Power and Energy Syst, 34 (1): 81-89.

[7] Bezmalinović D., Barbir F., Tolj I. 2013. Techno-economic analysis of PEM fuel cells role in photovoltaic-based systems for the remote base stations. Int. J. Hydrogen Energy, 38 (1): 417425.

[8] Hosseini M., Dincer I., Rosen M.A. 2013. Hybrid solar-fuel cell combined heat and power systems for residential applications: Energy and exergy analyses. J. Power Sources, 221: 372380 .

[9] Schlesinger H.I., Brown H.C., Finholt A. E., Gilbreath J.R., Hoekstra H.R., Hyde E.K. 1953. Sodium borohydride, its hydrolysis and its use as a reducing agent and in the generation of hydrogen. J. Am. Chem. Soc., 1: 215-219.

[10] Wu Y., Mohring R.M. 2003. Sodium borohydride for hydrogen storage. Prepr. Pap. Am. Chem. Soc. Div. Fuel Chem., 48: 940.

[11] Hua D., Hanxi Y., Xinping A., Chuansin C. 2003. Hydrogen production from catalytic hydrolysis of sodium borohydride solution using nickel boride catalyst. Int. J. Hydrogen Energy, 28: 10951100.

[12] Richardson B.S., Birdwell J.F., Pin F.G., Jansen J.F., Lind R.F. 2005. Sodium borohydride based hybrid power system. J. Power Sources, 145: 21-29.

[13] İnger E., Özdemir Z., Yaşar İ., Tırıs M., Bahar T., San F.G.B. 2006. Sodyum borhidrür üretimi ve doğrudan sodyum borhidrürlü yakıt pili üretimi ve entegrasyonu, Türkiye 10. Enerji Kongresi, 27-30 Kasim, İstanbul.

[14] Kojima Y., Suzuki K., Kawai Y. 2006. Hydrogen generation from lithium borohydride solution over nano-sized platinum dispersed on $\mathrm{LiCoO}_{2}$. J. Power Sources, 155: 325-328.

[15] Wee J.H., Lee K.Y., Kim S.H. 2006. Sodium borohydride as the hydrogen supplier for proton exchange membrane fuelcell systems. Fuel Processing Technology, 87: 811-819.

[16] Taner T. 2018. Energy and exergy analyze of PEM fuel cell: A case study of modeling and simulations. Energy, 143: 284-294.

[17] Wilberforce T., El-Hassan Z., Khatib F.N., Al Makky A., Mooney J., Barouaji A., Carton JG., Olabi AG. 2017. Development of Bi-polar plate design of PEM fuel cell using CFD techniques. Int. J. Hydrogen Energy, 42: 25663-25685.

[18] Wilberforce T., El-Hassan Z., Khatib F.N., Al Makky A., Mooney J., Barouaji A., Carton J.G., Thompson A., Olabi A.G. 2017. Modelling and simulation of proton exchange membrane fuel cell with serpentine bipolar plate using MATLAB. Int. J. Hydrogen Energy, 42: 25639-25662.

[19] Taner T. 2015. Alternative energy of the future: A technical note of PEM fuel cell water management. J. Fundamentals of Renewable Energy and Applications, 5(3): 1-4.

[20] Taner T., Naqvi S.A.H., Özkaymak M. 2017. Techno-economic analysis of a more efficient hydrogen generation system prototype: A case study of PEM electrolyzer with Cr-C coated SS304 bipolar plates. Fuel Cell, 1: 19-26.

[21] Taner T. 2017. The micro-scale modeling by experimental study in PEM fuel cell, J. Thermal Engineering. Yildız Technical University Press, 3(6): 1515-1526.

[22] Yılmaz A., Şevik S. 2017. Experimental analysis of electricity generation with sodium borohydride (NaBH4) assisted hydrogen/air PEM fuel cell. Batman University J. Life Sciences, 7(2/2): 216-227.

[23] Marrero-Alfonso E.Y., Gray J.R., Davis T.A., Matthews M.A. 2007. Minimizing water utilization in hydrolysis of sodium borohydride, the role of sodium metaborate hydrates. Int. J. Hydrogen Energy, 32: 4723-4730.

[24] Sammes N. 2005. Fuel cell technology-reaching towards commercialization. British Library Cataloguing in Publication Data, UK. 